\title{
Clinical Efficacy of a Specifically Targeted Antimicrobial Peptide Mouth Rinse: Targeted Elimination of Streptococcus mutans and Prevention of Demineralization
}

\author{
R. Sullivan ${ }^{a} \quad$ P. Santarpia ${ }^{a} \quad$ S. Lavender ${ }^{a} \quad$ E. Gittins ${ }^{a} \quad$ Z. Liu Li $^{a} \quad$ M.H. Anderson ${ }^{b}$ \\ J. He ${ }^{b}$ W. Shic R. Eckert ${ }^{b}$

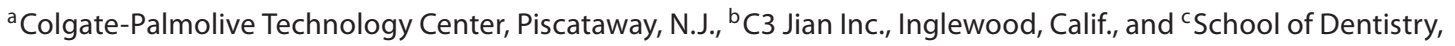 \\ University of California, Los Angeles, Calif., USA
}

\section{Key Words}

Antimicrobial $\cdot$ Antimicrobial peptide $\cdot$ Caries $\cdot$

Demineralization $\cdot$ Dental plaque $\cdot$ Lactic acid $\cdot$ Mouth rinse $\cdot$ Oral therapeutic $\cdot$ Selective antibiotic $\cdot$ Selective therapeutic - Specifically targeted antimicrobial peptide $\cdot$ Streptococcus mutans $\cdot$ Targeted antimicrobial

\begin{abstract}
Background/Aims: Streptococcus mutans, the major etiological agent of dental caries, has a measurable impact on domestic and global health care costs. Though persistent in the oral cavity despite conventional oral hygiene, S. mutans can be excluded from intact oral biofilms through competitive exclusion by other microorganisms. This suggests that therapies capable of selectively eliminating S. mutans while limiting the damage to the normal oral flora might be effective long-term interventions to fight cariogenesis. To meet this challenge, we designed C16G2, a novel synthetic specifically targeted antimicrobial peptide with specificity for S. mutans. C16G2 consists of a S. mutans-selective 'targeting region' comprised of a fragment from S. mutans competence stimulation peptide (CSP) conjoined to a 'killing region' consisting of a broad-spectrum antimicrobial peptide (G2). In vitro studies have indicated that $\mathrm{C} 16 \mathrm{G} 2$ has robust efficacy and
\end{abstract}

selectivity for S. mutans, and not other oral bacteria, and affects targeted bacteria within seconds of contact. Methods: In the present study, we evaluated C16G2 for clinical utility in vitro, followed by a pilot efficacy study to examine the impact of a $0.04 \%(w / v) ~ C 16 G 2$ rinse in an intra-oral remineralization/demineralization model. Results and Conclusions: C16G2 rinse usage was associated with reductions in plaque and salivary S. mutans, lactic acid production, and enamel demineralization. The impact on total plaque bacteria was minimal. These results suggest that C16G2 is effective against $S$. mutans in vivo and should be evaluated further in the clinic.

Copyright $\odot 2011$ S. Karger AG, Basel

Dental caries is a chronic infection that affects populations worldwide. In the United States alone, health care costs associated with treating dental caries have topped 64 billion USD annually [Evans and Kleinman, 2000; Anonymous, 2008]. In the developing world, dental caries is more prevalent, especially among pediatric patients,

C3 Jian Inc. acknowledges that C16G2 was under product development during this study.

\section{KARGER}

() 2011 S. Karger AG, Basel

Fax +41 613061234 E-Mail karger@karger.ch www.karger.com www.karger.com/cre
Randal Eckert

C3 Jian Inc.

423 Hindry Ave, Ste D

Inglewood, CA 90301 (USA)

Tel. +1 310665 2928, E-Mail reckert@ @3-jian.com 
and may be a result of a switch to 'Western' diets that feature high levels of dietary sugars [Beighton, 2005; Corby et al., 2005; Pitanga Fernandes et al., 2010]. Though not life-threatening, cavity formation is inversely related to quality of life and overall health. The bacterium Streptococcus mutans has been widely proposed as the major etiological agent of cavity formation, and upon intake of dietary sucrose, $S$. mutans will produce lactic acid that leeches calcium from hydroxyapatite surfaces and weakens tooth structure [Loesche, 1986; Tanzer et al., 2001].

Currently, the most effective measures for fighting caries involve the use of fluoride-containing products, most notably fluoride-containing varnishes, toothpastes, and silver diamine fluoride compounds, which are capable of preventing enamel demineralization and reversing the process through remineralization [Keyes and White, 1959; Koch et al., 1979; Williams and Cummins, 2003; Tom, 2011]. Although fluoride has been successful in reducing the incidence and prevalence of dental caries and should remain an important part of any anti-caries regimen, fluoride has limited efficacy in treating the root cause of caries, i.e. the cariogenic bacteria residing in dental plaque. This is one of the reasons caries persists in individuals and populations despite fluoride's well documented clinical efficacy [Beighton, 2005; Anderson and Shi, 2006; Tsang et al., 2006; Carounanidy and Sathyanarayanan, 2010].

Controlling caries by reducing the total bacterial load in saliva and plaque through use of broad-spectrum antibacterial agents can, in theory, reduce caries incidence; however, there are no clinical evidence supporting the long-term prevention of $S$. mutans re-infection and very few studies examining the impact on caries reduction [Tong et al., 2010; Vollmer et al., 2010; Young et al., 2010]. The reason for lack of long-term cavity protection is tied to the persistence of $S$. mutans within the dental plaque and the dynamic balance of the biofilm community between a healthy and cariogenic state. Individual behaviors with respect to oral hygiene and diet play a major role in determining whether dental plaque remains healthy or cariogenic. Broad killing of the bacteria alone allows for equal competition between $S$. mutans and nonpathogenic organisms to re-establish the biofilm. If an individual has poor oral hygiene and a diet high in refined sugars, the re-established biofilm will retain a community where cariogenic conditions persist and may dominate. In contrast, patients with 'healthy' dental plaque displaying low levels of $S$. mutans are resistant to exogenous colonization from cariogenic pathogens and have shown long-term protection from dental caries [Keene and Shklair, 1974;
Anderson and Shi, 2006; Tsang et al., 2006; He et al., 2009; Marsh, 2010]. There is a need to develop a specific antimicrobial therapy that can eliminate the primary agent of dental caries, $S$. mutans, from the oral biome while leaving the remaining organisms intact. If this can be achieved, the major initiator of caries, $S$. mutans, can be eliminated and a healthy biome established that may provide long-term caries protection.

Specific killing of $S$. mutans has been demonstrated in vitro by a series of novel synthetic peptide molecules known as specifically targeted antimicrobial peptides (STAMPs) [Eckert et al., 2006b; He et al., 2010]. One STAMP of particular interest, C16G2, consists of a novispirin-derived antimicrobial peptide (AMP) 'killing' region (G2) attached to a S. mutans-specific peptide pheromone 'targeting' region (C16). An increased rate of G2 accumulation on the bacterial surface, mediated by the targeting peptide, leads to rapid killing kinetics and selectivity for $S$. mutans versus other bacteria in the biofilm. C16G2 has been shown to specifically eliminate $S$. mutans, and not other oral streptococci, in both planktonic and saliva-derived biofilm systems. Additionally, intact S. mutans-free biofilms created by C16G2 intervention have been shown to resist colonization from exogenous S. mutans. C16G2 has a rapid mechanism of action, affecting bacteria in less than $1 \mathrm{~min}$ of exposure, and is soluble in aqueous solutions, suggesting that the STAMP is readily amendable for delivery to the oral cavity in a mouth rinse vehicle [Eckert et al., 2006a; He et al., 2010; Li et al., 2010; Kaplan et al., 2011].

This report explores the anti-S. mutans efficacy and safety of C16G2 in vitro and presents the results of a proof-of-concept clinical study to determine if the in vitro observations of efficacy translate to the more complex environment in the mouth. The clinical components investigated were: (1) efficacy of a single application of a STAMP-containing mouth rinse in the selective elimination of $S$. mutans in plaque and saliva, (2) its effects on plaque $\mathrm{pH}$ and lactic acid production after a sucrose challenge, and most importantly, (3) whether the STAMP effect on the plaque biofilm translates into a protective effect for enamel against bacteria-induced enamel demineralization throughout the course of a 4 -day test period.

\section{Materials and Methods}

Strains and Growth Conditions

Overnight cultures of $S$. mutans clinical isolate UA140 were grown in Todd-Hewitt (TH) broth under anaerobic conditions $\left(80 \% \mathrm{~N}_{2}, 10 \% \mathrm{CO}_{2}, 10 \% \mathrm{H}_{2}\right)$ at $37^{\circ} \mathrm{C}$. To form biofilms, bacteria 
were seeded from overnight cultures to a final concentration of $\sim 1 \times 10^{5} \mathrm{cfu} /$ well in 48 -well microplates $(400 \mu \mathrm{l}$ per well) in $\mathrm{TH}$ supplemented with $1 \%(\mathrm{v} / \mathrm{v})$ sucrose and grown $17-24 \mathrm{~h}$ at $37^{\circ} \mathrm{C}$ under an anaerobic atmosphere.

\section{Peptide Synthesis}

C16G2 (TFFRLFNRSFTQALGKGGGKNLRIIRKGIHIIKKY, amidated C-terminus), acetate salt, was synthesized by conventional 9-fluorenylmethyloxycarbonyl (Fmoc) chemistry by Chinese Peptide Company (Hangzhou, China). Expected peptide molecular mass $(4,078.9)$ was confirmed by electrospray ionization mass spectroscopy and the peptide HPLC purified to $98.4 \%$ by the manufacturer (data not shown) and lyophilized. C16G2 was synthesized under Good Manufacturing Practice conditions.

G2 (KNLRIIRKGIHIIKKY, amidated C-terminus) and Melittin B (GIGAVLKVLTTGLPALISWIKRKRQQ) were synthesized by Fmoc chemistry using the appropriate Wang and Rink Amide MBHA resins and purified to $\sim 90 \%$ by RP-HPLC (GL Biochem, Shanghai, China), according to the manufacturer's specifications (data not shown).

\section{Determination of Anti-Biofilm Activity}

The in vitro anti-S. mutans biofilm activity of C16G2, parent AMP G2, or Melittin B, was evaluated with resazurin, a redox metabolic indicator dye, using an adaptation of the manufacturer's instructions (CellTiterBlue, Promega, Madison, Wisc., USA). Mature UA140 biofilms were first treated with C16G2 by replacement of culture supernatant with peptide (freshly prepared) in $200 \mu \mathrm{l} 1 \times$ PBS. Mock-treated biofilms were exposed to $1 \times$ PBS alone, while positive-control biofilms were treated with $70 \%(\mathrm{v} / \mathrm{v})$ ethanol. After $20 \mathrm{~min}$ incubation at room temperature with orbital shaking, the test solutions were replaced with $150 \mu \mathrm{l} \mathrm{CellTi-}$ terBlue reagent in $\mathrm{TH}$ broth $(1 \mathrm{ml} / 7.5 \mathrm{ml} \mathrm{TH})$. The metabolic activity of biofilms was then monitored for $10 \mathrm{~min}$ at $37^{\circ} \mathrm{C}$ (enough time for mock-treated cultures to reduce the blue reagent to pink). Biofilm viability was recorded by transferring $100 \mu$ l of converted reagent to a 96-well plate and recording the absorbance at $570 \mathrm{~nm}$ (maximum absorbance for the converted substrate resorufin, Cary 50 spectrophotometer, Agilent, Santa Clara, Calif., USA). Biofilm viability after peptide exposure was plotted as a percentage of mock-treated cultures, with $0 \%$ viability set as the redox activity from ethanol-sterilized biofilms. Experiments were conducted in at least 3 replicates with average values plotted.

\section{STAMP Hemolytic Activity}

Experiments similar to those utilized to evaluate conventional AMPs were employed to determine STAMP-mediated hemolysis of human red blood cells (RBCs) [Sawai et al., 2002; Zhu et al., 2007; Vaucher et al., 2010]. Briefly, 2-fold serial dilutions of C16G2 or Melittin B (3.125 to $200 \mu \mathrm{M})$ were combined with $2.5 \%(\mathrm{v} / \mathrm{v})$ human RBCs (Fisher Scientific, Pittsburgh, Pa., USA) in $1 \times$ PBS and incubated $30 \mathrm{~min}$ at $37^{\circ} \mathrm{C}$. RBCs were then centrifuged and the supernatants collected and analyzed for absorbance at $540 \mathrm{~nm}$. Data were expressed as a percentage of total heme release from positive control samples (1\% Triton X-100, ' $100 \%$ lysis'): $\left(\mathrm{OD}_{540}\right.$ sample - $\mathrm{OD}_{540}$ no lysis $) /\left(\mathrm{OD}_{540} 100 \%\right.$ lysis - $\mathrm{OD}_{540}$ no lysis) $\cdot 100$. Percent hemolysis was shown as the average of independent experiments conducted in triplicate.

\section{In vitro Oral Tissue Irritation}

Mucosal irritation (as measured by the effective time for reduction of $50 \%$ of tissue viability) associated with C16G2-containing $1 \times$ PBS was investigated in vitro utilizing a classical MTT (3-(4,5-dimethylthiazol-2-yl)-2,5-diphenyltetrazolium bromide) assay and single-donor human-derived oral tissue. Eight to 11 cell layers of EpiOral (buccal) and EpiGingival tissue (MatTek, Ashland, Mass., USA) were differentiated from non-transformed, non-diseased human oral keratinocytes by the manufacturer. Tissues were maintained on collagen-coated single-well tissue culture plate inserts (Millicell, Millipore, Billerica, Mass., USA) and utilized within 2 days of receipt. All reagents and proprietary media were provided by MatTek.

Briefly, tissue inserts were transferred to 6 -well plates containing pre-warmed media and equilibrated overnight $\left(37^{\circ} \mathrm{C}, 5 \%\right.$ $\mathrm{CO}_{2}$ ), followed by exposure (apical surface) to $100 \mu \mathrm{l}$ of 25 or $100 \mu \mathrm{M}$ C16G2 in $1 \times$ PBS, $1 \times$ PBS alone (negative control for irritation), or Triton X-100 (positive control). The duration of exposure was $20 \mathrm{~min}, 1 \mathrm{~h}$ or $4 \mathrm{~h}$ for EpiOral, and 1, 4 and $18 \mathrm{~h}$ for EpiGingival, based on the manufacturer's recommendation. At each time point, the agent was removed and tissues rinsed twice with $1 \times$ PBS and placed in new 24-well plates containing $300 \mu \mathrm{MTT}$ solution for $3 \mathrm{~h}\left(37^{\circ} \mathrm{C}, 5 \% \mathrm{CO}_{2}\right)$. After incubation, formazan was extracted from tissues by immersion in $2 \mathrm{ml}$ of extraction solution (MatTek) for $2 \mathrm{~h}$, followed by measurement of absorbance at $570 \mathrm{~nm}$, with extraction solution alone as a blank. Percent viability was calculated as a percentage of Abs570 from $1 \times$ PBS-treated tissues. The ET-50 was determined for Triton X-100-treated samples by plotting percent viability versus dosage time and estimating the duration at $50 \%$ viability.

Detection and Stability of C16G2 in $1 \times$ PBS and Saliva

Peptide was monitored by LC-MS (Xbridge BEH C18 $5 \times$ $130 \mathrm{~mm}$ column, Waters 2996 photodiode detector and $3100 \mathrm{ESI}$ mass detector, Waters, Milford, Mass., USA) in $1 \times$ PBS or pooled human saliva ( $\sim 25$ healthy anonymous volunteers) after the durations indicated. Saliva was prepared by centrifuging at $4,200 \mathrm{~g}$ for $10 \mathrm{~min}$ and filtering twice $(0.22 \mu \mathrm{m})$. For each LC run, an $\mathrm{H}_{2} \mathrm{O}$ / ACN (with $0.01 \%$ TFA) gradient from $10-90 \%$ mobile phase was utilized over $15 \mathrm{~min}$. The injection volume was $20 \mu \mathrm{l}$ for all samples. Utilizing these methods, the lowest reproducible detectable C16G2 concentration in $1 \times$ PBS or prepared saliva was $3.8 \mu \mathrm{M}$ (data not shown).

To measure C16G2 stability in $1 \times$ PBS, the peptide was dissolved directly into buffer at $100 \mu \mathrm{M}$. Samples were kept at $25^{\circ} \mathrm{C}$ or $4^{\circ} \mathrm{C}$ and filtered $(0.22 \mu \mathrm{m})$ before injection. Stability was assessed at $4 \mathrm{~h}$ and $24 \mathrm{~h}$ after dose preparation by comparing the peak area for C16G2 to the immediately prepared reference sample. To measure stability in saliva, a $200 \mu \mathrm{M}$ C16G2 solution in $1 \times$ PBS was diluted to $50 \%(\mathrm{v} / \mathrm{v})$ in prepared saliva and samples collected at defined intervals. C16G2 peak area was examined (after subtraction of saliva baseline spectra), plotted versus incubation time, and fit to a single-order decay equation to determine half-life using Kaleidagraph (Synergy Software, Reading, Pa., USA).

\section{Procedure for Preparing Bovine Enamel Blocks}

To prepare the bovine enamel specimens, bovine teeth were ground and polished into $\sim 4 \times 4 \times 1 \mathrm{~mm}$ blocks. The blocks were cleaned, rinsed with distilled water, and sterilized by ethyl- 
ene oxide for $4 \mathrm{~h}$. When not in use during the preparatory phase, blocks were stored in distilled water at $4^{\circ} \mathrm{C}$.

Briefly, in the grinding step, blocks were flattened by a variable speed grinder polisher (15u diamond polishing disc; Buehler, Lake Bluff, Ill., USA). The dentin and enamel sides were ground flat at $100 \mathrm{rpm}$ for 2.5 and $5 \mathrm{~min}$, respectively. For polishing, a polishing cloth was fitted to the polishing disc and a diamond suspension, Metadi 6u (Buehler, Lake Bluff, Ill., USA), was sprayed to evenly cover the cloth. Blocks were placed enamel side down, and the system was run for $10 \mathrm{~min}$ at $100 \mathrm{rpm}$, followed by rinsing with 21 of water, and the polishing cycle repeated. Post-polishing, the blocks were washed with $25 \mathrm{ml} \mathrm{10 \%} \mathrm{(w/w)} \mathrm{Alconox} \mathrm{solution}$ (VWR, West Chester, Pa., USA) poured onto the polishing cloth (run for $1 \mathrm{~min}$ ) before the blocks had a final rinse using $4 \mathrm{l}$ of water over 5 min. Blocks were then sonicated (Branson 1200, Branson Ultrasonics, Danbury, Conn., USA) with distilled water for cycles of 10 min until foaming, suds and cloudiness ceased.

\section{Preparation of Retainers for the Intra-Oral Study}

Customized retainers (fig. 1) were prepared by first casting an impression of the upper maxillary palate of each subject. Once the impressions were made, a sheet of $0.020 \mathrm{~cm}$ thick vacuum forming plastic material (Buffalo Dental Mfg. Syosset, N.Y., USA) was molded to fit across each subject's roof of the mouth and to conform to molar teeth on either side of mouth.

Holes were punched into each of the retainers in order to expose the surface of the bovine enamel blocks to the treatment being used. Two blocks measuring approximately $4 \times 4 \times 1 \mathrm{~mm}$ were placed on both the right and left side of the retainer. They were secured by drilling several small holes on the sides of the punched-out mounting area and stitching dental floss in the back of the blocks. A thin sheet of soft dental orthodontic tray wax (Kerr, Romulus, Mich., USA) was placed across the back of the blocks to secure them into place. Before placing the blocks into the retainer, they were covered with a sheet of wire mesh. The wire mesh was used to accumulate plaque over the 5-day treatment period.

\section{Clinical Study Design}

Figure 2 provides an overview of the study design. Twelve subjects were selected for the study from an established pool of volunteer subjects at the Colgate-Palmolive Technology Center in Piscataway, N.Y., USA. The inclusion criteria for the study included good general health, a minimum of 20 natural uncrowned teeth (excluding third molars) and age between 18 and 65 years. The exclusion criteria included advanced periodontal disease or diseases of the hard or soft tissue, five or more decayed dental sites, a medical condition that required premedication prior to dental visits, a medical condition that would prevent rinsing with a sucrose solution, an immune-compromising medical condition, antibiotic use 1 month prior to or during the study, medication that affected salivary flow or impaired salivary flow, use of orthodontic appliances, use of tobacco products and pregnancy or breastfeeding. Before the start of the study, it was approved by the Colgate-Palmolive's institutional review board and all subjects signed an informed consent form. Prior to each of the two treatment phases, which consisted of 5 days each, the subjects had a dental prophylaxis and received a soft toothbrush and a nonfluoride toothpaste to serve as a washout to help remove the effects of the influence of fluoride during the course of the study.

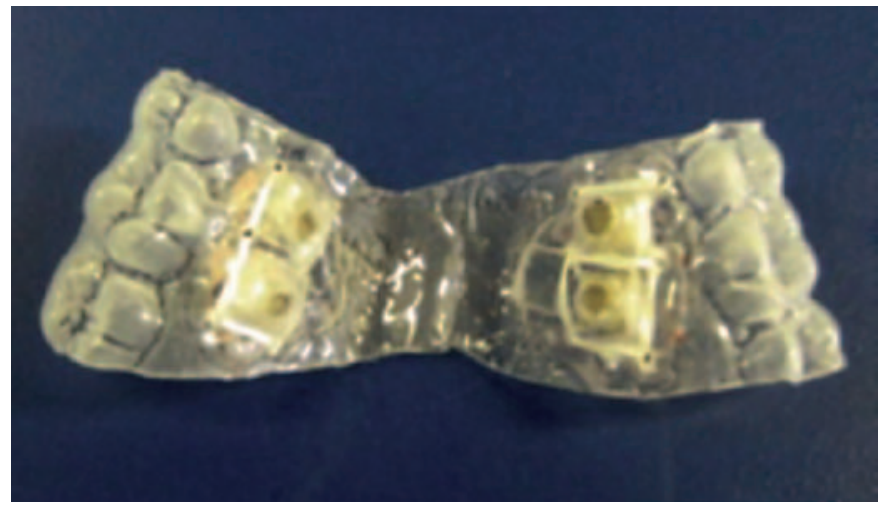

Fig. 1. Intra-oral retainer. Sites for loading enamel chips can be seen on the left and right sides (circular punches in square mounts).

The subjects were instructed to brush with this toothpaste twice per day as they normally would for a period of 9 days. This study also utilized an intra-oral demineralization/remineralization model in which mineral changes (before and after each treatment) were measured by microhardness. The subjects wore an intra-oral upper palatal retainer (fig. 1) containing four prepared bovine enamel specimens. These enamel blocks were covered with a metal wire mesh to accumulate plaque during the treatment phases.

On the first day of either treatment phase (baseline), the subjects arrived at the dental clinic without morning oral hygiene and without eating or drinking from the previous evening and fasting plaque was collected. All plaque was collected on ice and put into pre-weighed vials. The plaque was collected by scrapping the entire right side (both upper and lower arches) dentition and pooled. The resting plaque $\mathrm{pH}$ or plaque $\mathrm{pH}$ before a sucrose challenge was measured. This same plaque was analyzed for $S$. mutans cfu/ $\mathrm{ml}$. Resting whole saliva was also collected for $S$. mutans analysis. After the plaque and whole saliva collections, the subjects rinsed with a $10 \%$ sucrose solution for 2 min using a method adapted from one previously described [Damen et al., 2002]. Eight minutes after this sucrose rinse, a second plaque sample was collected by scraping the entire left side (both upper and lower arches) dentition. This pooled plaque sample was used for lactic acid analysis. Plaque collections for subsequent time point assessments were alternated between the right and left sides. After the collections, the intra-oral mouth retainers were put into the mouth, and the subjects rinsed for $40 \mathrm{~s}$ with a mouth rinse. In the first 5-day treatment phase, the subjects used the placebo mouth rinse ( $1 \times \mathrm{PBS})$; in the second 5-day treatment phase, the subjects used the $0.04 \%$ (w/v) STAMP-containing mouth rinse. The subjects were also given a new soft toothbrush and a non-fluoride toothpaste to use for each 5-day treatment phase. They were instructed to brush their teeth but not the intra-oral mouth retainer containing the bovine blocks twice per day in the morning and before going to bed for $1 \mathrm{~min}$ followed by a $10 \mathrm{~s}$ rinse with tap water. They were also instructed to dip the mouth retainers into a $10 \%$ sucrose solution 4 times per day at approximately 9:00 AM, 11:00 AM, 4:00 PM and 7:00 PM for $10 \mathrm{~min}$ each time. The retainer was worn 


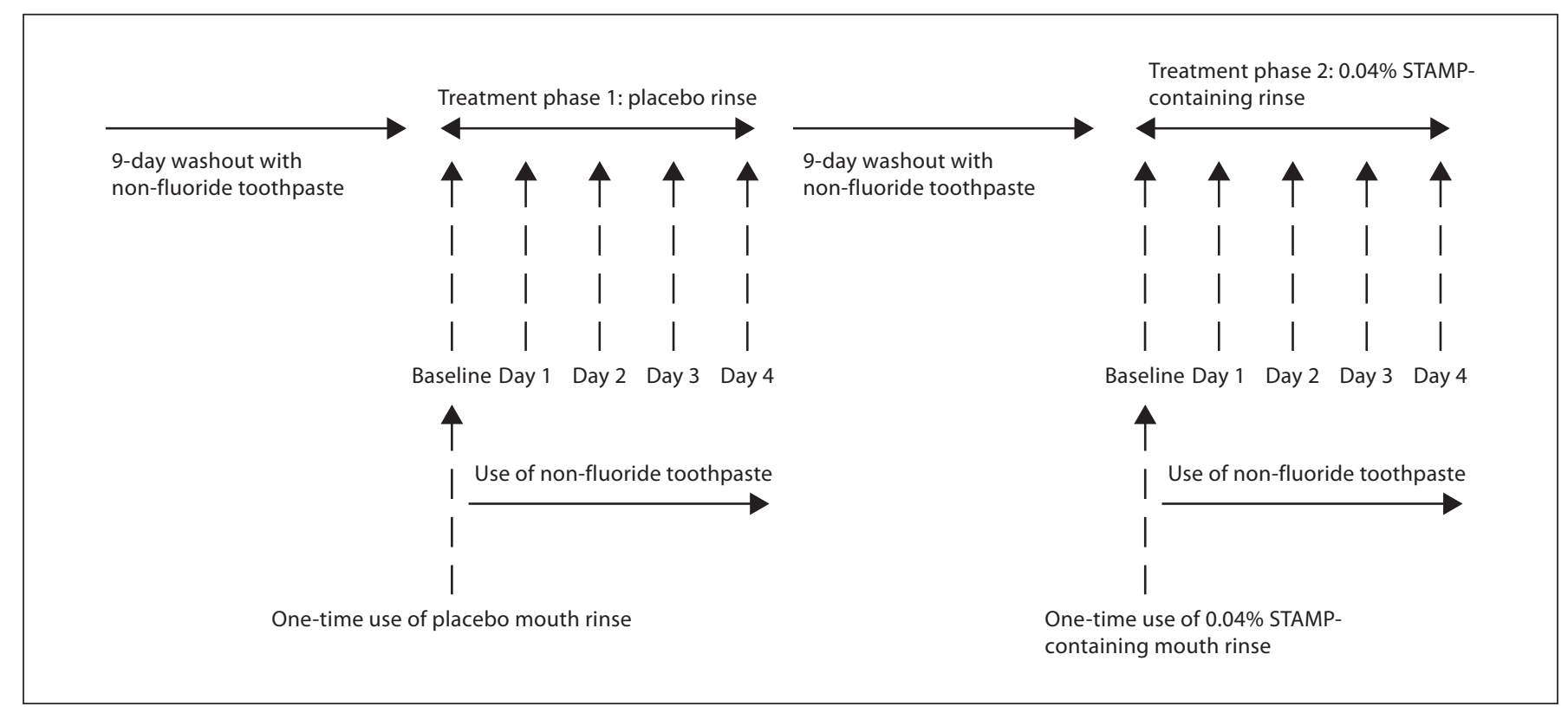

Fig. 2. Clinical study design.

all day including sleeping for each treatment phase. Subjects were only allowed to remove it during meal time and to clean under tap water. No other oral care product was used during the course of the study.

On the second, third, fourth and fifth days after treatment (day 1, day 2, day 3 and day 4, respectively), the subjects arrived at the dental clinic without morning oral hygiene and without eating or drinking from the previous evening. As described above, fasting plaque for resting plaque $\mathrm{pH}$ analysis and resting whole saliva counts for total bacteria and $S$. mutans analysis were collected before a sucrose rinse. Plaque was collected after the sucrose rinse for lactic acid analysis. After the collections, one enamel block was removed on day 2 and one on day 4 , and the plaque that accumulated was removed for enumeration of $S$. $m u$ tans, other oral streptococci, and total bacteria by RT-PCR. Also on day 4 , the remaining two enamel blocks were removed and assessed for microhardness.

\section{Assessment of S. mutans in Plaque and Saliva}

To assess the impact of C16G2 on salivary and plaque populations of $S$. mutans, antibody staining and plating experiments were conducted, respectively. To examine the level of $S$. mutans $\mathrm{cfu} / \mathrm{ml}$ in plaque before sucrose challenge, plaque samples were sonicated (Microson Ultrasonic Cell Disruptor XL, Misonix Inc., Famingdale, N.Y., USA) for $20 \mathrm{~s}$ at $15 \mathrm{~W}$ and vortexed repeatedly to disrupt bacterial aggregates after the plaque $\mathrm{pH}$ was taken. Serial dilutions of plaque suspensions were then made in $1 \times$ PBS, and aliquots plated on $S$. mutans-selective Mitis Salivarius Agar supplemented with valinomycin $(0.01 \mathrm{mg} / \mathrm{ml})$, bacitracin $(0.3 \mathrm{U} /$ $\mathrm{ml})$, sulfisoxazole $(0.2 \mathrm{mg} / \mathrm{ml})$, and $0.001 \%$ potassium tellurite $(\mathrm{w} / \mathrm{v})$ to quantitate surviving $\mathrm{cfu} / \mathrm{ml}$. Surviving cfu were normalized by plaque weight and expressed as the deviation from baseline samples.

Clinical Efficacy of a Specifically Targeted Antimicrobial Peptide Mouth Rinse
The number of $S$. mutans in saliva was assessed by antibody staining, a technique that can be rapidly and accurately performed in this matrix, as described previously [Gu et al., 2002]. Unstimulated saliva samples $(1-2 \mathrm{ml})$ were obtained from panelists each morning (prior to treatment) and immediately placed on ice. After vortexing, $500 \mu \mathrm{l}$ aliquots were added to a capped centrifuge tube ( $2 \mathrm{ml}$, Fisher Scientific) containing $50 \mu \mathrm{l}$ of $10 \%(\mathrm{v} / \mathrm{v})$ formaldehyde. Fixed samples were then protected from light and stored at $4^{\circ} \mathrm{C}$ until analysis by fluorescence microscopy (Nikon E400 microscope).

\section{Determination of Resting Plaque $\mathrm{pH}$ and Lactic Acid \\ Production}

Plaque $\mathrm{pH}$ was determined by use of a $\mathrm{pH}$ microelectrode (Microelectrodes Inc., Bedford, N.H., USA). All plaque $\mathrm{pH}$ values were taken immediately following collection at the chair side. The method for determining lactic acid concentration in plaque samples was adapted from previously published methods [Damen et al., 2002; Gerardu et al., 2007]. The samples were heated to $80^{\circ} \mathrm{C}$ for $5 \mathrm{~min}$ to kill the bacteria and release all acids, and the concentration of lactic acid in the supernatant was measured as the lactate anion using capillary electrophoresis, as described previously [Izco et al., 2002]. Briefly, separations were carried out on a fused silica capillary with an effective length of $50 \mathrm{~cm}$ and an internal diameter of $50 \mu \mathrm{m}$. The optimized buffer system consisted of $20 \mathrm{~mm}$ 2,6-pyridine dicarboxylic acid and $0.5 \mathrm{~mm}$ hexadecyltrimethyl ammonium bromide, pH 5.66 (Sigma-Aldrich).

\section{Enumeration of Bacteria by RT-PCR}

RT-PCR was utilized to gauge antimicrobial activity and selectivity by measurement of $S$. mutans and total bacteria after the STAMP or placebo treatment periods. Plaque was removed from the enamel blocks and stored in a $-80^{\circ} \mathrm{C}$ freezer until analysis. 
DNA extraction and purification was carried out following a 3-step procedure that utilized the Puregene ${ }^{\mathrm{TM}}$ Yeast/Bacterial Kit (Puregene Kit, Qiagen, Valencia, Calif., USA), and a FastPrep 120 Bead-beater (Thermo-Fisher, Pittsburgh, Pa., USA): (1) mechanical pretreatment; (2) chemical and enzymatic pretreatment; (3) silica beads-based DNA extraction.

For (1), plaque samples were resuspended in $700 \mu \mathrm{l}$ of Cell Suspension Solution (Puregene Kit) and transferred into a tube containing beads (Lysing Matrix B tubes, MP Biomedical, Solon, Ohio, USA) and the slurry was mixed by vortexing. Bead-beating was then performed for 3 runs at a speed setting of 5.5 for $20 \mathrm{~s}$ during each run, with $20 \mathrm{~s}$ between sequential runs. Tubes containing slurry were then centrifuged at 13,000 rpm for $10 \mathrm{~min}$ and $200 \mu \mathrm{l}$ of sample supernatants were transferred to new tubes for continued processing, while the remaining supernatant was collected and stored at $-40^{\circ} \mathrm{C}$.

For (2), $10 \mu$ l Lytic Enzyme Solution (Puregene Kit) was added to each sample followed by incubation at $37^{\circ} \mathrm{C}$ for $30 \mathrm{~min}$ with manual inversion every $10 \mathrm{~min}$. After incubation, $95 \mu \mathrm{l}$ of Cell Lysis Solution (Puregene Kit) was added and the tubes were inverted 20 times followed by incubation at $80^{\circ} \mathrm{C}$ for $5 \mathrm{~min}$ to complete the lysis. Samples were then cooled for $10 \mathrm{~min}$ at ambient temperature. RNase $(10 \mu \mathrm{l})$ was then added and the samples were heated to $37^{\circ} \mathrm{C}$ and mixed by inversion as described for the lytical enzyme step. After incubation, a $200 \mu \mathrm{l}$ aliquot of the liquid was transferred to a new tube for subsequent automated DNA extraction and the remainder was stored at $-40^{\circ} \mathrm{C}$.

For (3), DNA extraction and purification was performed utilizing the Qiagen MagAttract DNA Blood Midi M48 Kit (X27231KIT, Qiagen) on a Qiagen BioRobot M48 robot (200 $\mu$ l Blood Protocol). Upon completion, extracted DNA was suspended in $50 \mu \mathrm{l}$ of RNase-free water.

The S. mutans genomic DNA standard sample was purchased from ATCC (ATCC, Manassas, Va., USA). The S. mutans genomic DNA stock was prepared by reconstituting $10 \mu \mathrm{g}$ of DNA in $1,600 \mu \mathrm{l}$ of water. The standard was used in 10 -fold serial dilutions. The $S$. mutans forward primer sequence was $5^{\prime}$-CTG AGA GGG TGA TCG G-3', and the reverse primer sequence was 5'-ACA CTA TGG TTG AGC CAT-3' with an amplicon size of $338 \mathrm{bp}$. The total bacteria forward primer sequence was $5^{\prime}$-ACA GGA TTA GAT ACC CTG G-3', and the reverse primer sequence was R: 5'-ACA TCT CAC GAC ACG AG-3' with an amplicon size of $314 \mathrm{bp}$ (Invitrogen, Carlsbad, Calif., USA).

Real-Time PCR analysis was carried out on a Roche LightCycler $^{\circledR} 480$ System. A reaction mixture was prepared by mixing $1 \mu \mathrm{l}$ forward and reverse primers ( $5 \mu \mathrm{M}$ stocks), $0.6 \mu \mathrm{l}$ of DNasefree water, $10 \mu \mathrm{l}$ of LightCycler ${ }^{\circledR} 480$ SYBR Green I Mastermix (Roche, Basel, Switzerland) and $2.4 \mu \mathrm{l}$ of magnesium chloride stock solution ( $25 \mathrm{~mm}$ stock, Roche). $15 \mu$ l of the mixture was pipetted into each well of a 384 -well plate (Roche), to which a $5 \mu \mathrm{l}$ experimental sample or standard was added. The plates were then sealed using a LightCycler ${ }^{\circledR} 480$ Sealing Foil (Roche) and centrifuged for $2 \mathrm{~min}$ at $1,000 \mathrm{~g}$. The temperature programs comprised a pre-incubation step $\left(95^{\circ} \mathrm{C}\right.$ for $\left.10 \mathrm{~min}\right)$, a subsequent amplification (denaturing at $95^{\circ} \mathrm{C}$ for $10 \mathrm{~min} /$ annealing at $55^{\circ} \mathrm{C}$ for $5 \mathrm{~s} /$ extension at $72^{\circ} \mathrm{C}$ for $12 \mathrm{~s}$ ) step repeated for a total of 45 cycles, a melting point determination step and finally a cooling step $\left(40^{\circ} \mathrm{C}\right)$. A standard curve for quantifying the specific DNA concentration of the unknown samples was generated using the $\mathrm{Ct}$ values and known concentrations.
Microhardness Testing of Bovine Enamel Blocks

The microhardness of the enamel blocks was determined using a Micromet 5101 Microhardness Tester with Knoop Diamond Indenter and a $50 \mathrm{~g}$ load (Buehler, Lake Bluff, Ill., USA), before and after treatment periods. Baseline indents were required to be symmetrical and readings no greater than 55-60 $\mu \mathrm{m}$. Blocks were gently buffed with a dry micro-cloth before testing to both dry the block and remove any surface contaminant. Five indents were made at $0.01 \mathrm{~mm}$ every $15 \mathrm{~s}$. The indent lengths were averaged and Knoop microhardness value for the baseline enamel hardness was calculated. The extent of mineral loss before and after the treatment change was expressed as the change in enamel microhardness and the percent loss in enamel hardness relative to baseline.

\section{Statistical Analysis}

All statistical analyses were performed using Minitab ${ }^{\circledR} 15.1 .0 .0$ (Minitab, Inc., State College, Pa., USA). A repeated measures multifactor ANCOVA was used to analyze microbiology, RT-PCR, plaque $\mathrm{pH}$, and lactic acid production data. The baseline values were used as the covariate. Treatment, time, panelist, and treatment $\cdot$ day were used as factors. Panelist and treatment were treated as random factors. A paired t test was used to make individual time point comparisons when warranted. Differences were considered significant at a 95\% confidence level (two-way test). The microhardness data were analyzed using two-factor ANOVA using treatment and panelist as factors. Differences were considered significant if a 95\% confidence level was achieved in a two-way test.

\section{Results}

\section{C16G2 Activity against in vitro Biofilms}

C16G2 has demonstrated efficacy and specificity against $S$. mutans in mixed biofilm communities and planktonic cultures [Eckert et al., 2006a; Li et al., 2010]. However, it was unclear whether C16G2 would remain active when formulated in a preliminary mouth rinse of $1 \times$ PBS, or if the STAMP would have activity when challenged by an in vitro system of high density $\left(\sim 1 \times 10^{9}\right.$ $\mathrm{cfu} / \mathrm{ml}$ ) single-species biofilms of $S$. mutans grown in $1 \%$ sucrose. C16G2 was investigated in this system to confirm activity at a level that would lend confidence to possible clinical applications, and to compare its activity to G2 (parental AMP) and the toxic AMP Melittin B [Fennell et al., 1967]. The metabolic activity of biofilms treated with peptide was monitored by a standard redox colorimetric system similar to a classical MTT assay [Gobor et al., 2011].

As shown in figure 3, freshly prepared serial dilutions of C16G2 in $1 \times$ PBS reduced the viability of $S$. mutans biofilms to below $10 \%$ of mock-treated controls. This level of activity was noticeably greater than that of G2 (all concentrations examined) and Melittin B at $25 \mu \mathrm{M}$. These data strongly suggest that C16G2 is highly active against 
Fig. 3. Activity of C16G2 against $S$. mutans biofilms. UA140 biofilms were grown $24 \mathrm{~h}$ under anaerobic conditions with $1 \%(\mathrm{w} / \mathrm{v})$ sucrose. Biofilm viability was then assessed by a substrate-conversion redox assay after treatment with C16G2, G2, or Melittin B at the concentrations indicated. Biofilms treated with buffer alone were considered as having $100 \%$ viability.

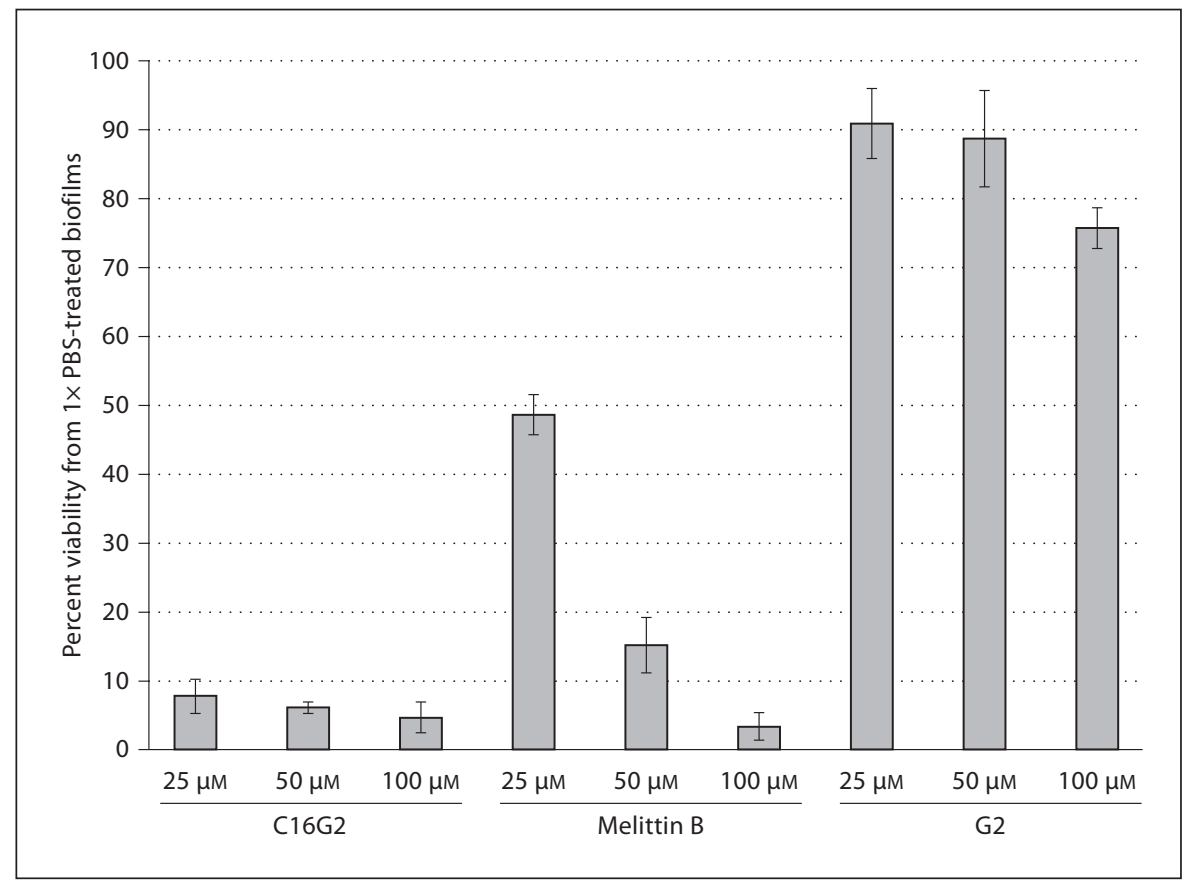

Table 1. Percent hemolytic activity against human RBCs, $\mu \mathrm{M}$

\begin{tabular}{llllllll}
\hline Peptide & $3.125 \mu \mathrm{M}$ & $6.25 \mu \mathrm{M}$ & $12.5 \mu \mathrm{M}$ & $25 \mu \mathrm{M}$ & $50 \mu \mathrm{M}$ & $100 \mu \mathrm{M}$ & $200 \mu \mathrm{M}$ \\
\hline C16G2 & -0.58663 & -1.0060 & 1.109437 & 1.401234 & 0.234046 & 0.908826 \\
G2 & -1.0608 & -1.3526 & 0.726453 & 1.56537 & 1.364759 & 0.252283 \\
Melittin B & 0.2721 & 8.1018 & 53.1332 & 84.6824 & 86.1060 & 85.9593 & 77.644503 \\
\hline
\end{tabular}

Data are expressed as percent of total heme release from positive control samples (1\% Triton X-100) and represent the average of 3 independent experiments.

robust mature $S$. mutans biofilms at therapeutic concentrations of 25-100 $\mu \mathrm{M}$, and that the STAMP has potential to treat sucrose-derived biofilms in vivo.

\section{C16G2 Cytotoxicity}

In vitro hemolysis and tissue irritation assays were utilized to examine STAMP activity against human cells. As shown in table 1, C16G2 had no hemolytic activity against human RBCs at concentrations $100 \mu \mathrm{M}$ or below, and displayed less than $15 \%$ hemolysis at $200 \mu \mathrm{M}$. In contrast, Melittin B had robust hemolytic activity at concentrations as low as $12.5 \mu \mathrm{M}(\sim 53 \%)$, as expected [Blondelle et al., 1993]. These data are suggestive of an acceptable STAMP safety profile at potential therapeutic concentrations of 25-100 $\mu \mathrm{M}$.

Clinical Efficacy of a Specifically Targeted Antimicrobial Peptide Mouth Rinse
To further assess cytotoxicity, the impact of C16G2 treatment on human tissue in vitro was explored. Fully differentiated buccal (EpiOral) and gingival (EpiGingival) tissues from healthy donors were cultivated in vitro and exposed to Triton X-100 (positive control) or C16G2 $(25$ or $100 \mu \mathrm{M})$ in $1 \times$ PBS. After incubation for the durations indicated, the viability of tissues was ascertained by an MTT assay. As shown in figure 4, no ET-50 (time to reduce tissue viability to $50 \%$ ) could be obtained for STAMP-treated EpiOral (fig. 4a) or EpiGingival (fig. 4b) tissue. In contrast, an expected ET-50 of $\sim 1 \mathrm{~h}$ and $11 \mathrm{~h}$ was obtained from EpiOral and EpiGingival tissue, respectively, treated with Triton X-100, indicating the expected moderate levels of irritation. Taken together the data in table 1 and figure 4 suggest that C16G2 has little activity

Caries Res 2011;45:415-428 

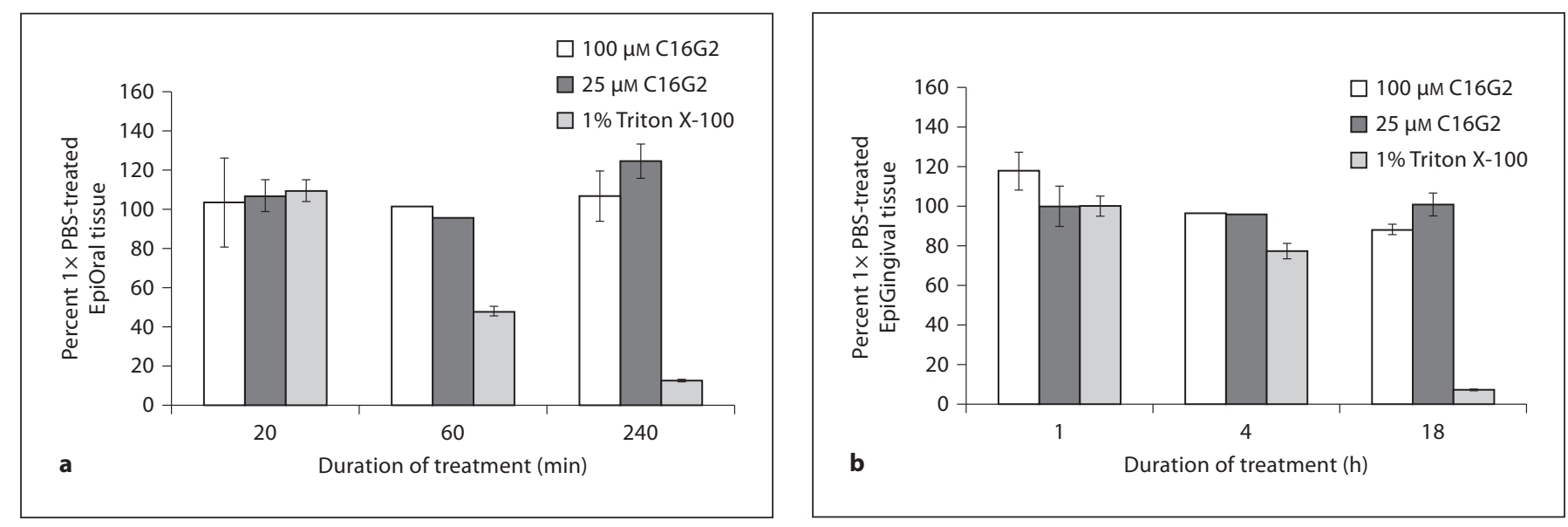

Fig. 4. In vitro tissue irritation. EpiOral (a) or EpiGingival (b) tissue was exposed to 25 or $100 \mu \mathrm{M} \mathrm{C} 16 \mathrm{G} 2$, or $1 \%$ Triton X-100, for the durations indicated. Tissue viability was recorded by a substrate conversion assay (MTT) and expressed as percentage of viability from $1 \times$ PBS-treated tissue. ET-50 (time to 50\% viability) was estimated for Triton X-100-treated samples.

against isolated human cells or defined tissue when dissolved in $1 \times \mathrm{PBS}$ at potential therapeutic concentrations.

\section{Stability of C16G2 in 1× PBS and Human Saliva}

The stability of $\mathrm{C} 16 \mathrm{G} 2$ in a rudimentary mouth rinse and in pooled human saliva was assessed to gauge peptide clinical utility and amenability to future formulation development. In the initial experiment, $100 \mu \mathrm{M} \mathrm{C16G2}$ was mixed with $1 \times$ PBS and monitored over time at 25 and $4^{\circ} \mathrm{C}$ by LC/MS. As shown in figure $5 \mathrm{a}$, total ion counts (TIC) were collected and single peaks corresponding to acetate $(\sim 3.2 \mathrm{~min})$ and C16G2 $(\sim 8.4 \mathrm{~min}$, observed $\mathrm{m} / \mathrm{z}$ species $[\mathrm{M}]^{4+} 1020.45$, expected $\left.\mathrm{m} / \mathrm{z}[\mathrm{M}]^{4+} 1019.74\right)$ were observed for immediately prepared samples $(t=0)$. These peaks were also observed when examining spectra collected by the photodiode array ( $215 \mathrm{~nm}$, data not shown). As expected, the acetate peak remained largely unchanged for samples incubated $20 \mathrm{~h}$ at either 4 or $25^{\circ} \mathrm{C}$. The peak shape was retained for $\mathrm{C} 16 \mathrm{G} 2$ held at $4^{\circ} \mathrm{C}$ over the course of the experiment, where the percentage of initial peak area after $20 \mathrm{~h}$ was $98.99 \%$. In contrast, a degradant shoulder peak appeared in samples kept at $25^{\circ} \mathrm{C}$ for $20 \mathrm{~h}$, and the percent C16G2 peak area dropped to $83 \%$ of the immediately prepared standards. Subsequent analysis indicated that C16G2 peak area was stable through $4 \mathrm{~h}$ at $25^{\circ} \mathrm{C}$ (percent area of $0 \mathrm{~h}$ peak at $4 \mathrm{~h}=95.53 \%$ ), as was peak shape (data not shown), indicating that C16G2 becomes unstable in $1 \times \mathrm{PBS}$ after $4 \mathrm{~h}$ at $25^{\circ} \mathrm{C}$.
Next, we estimated the half-life of C16G2 in saliva, which contains numerous protease and peptidase components that should hypothetically degrade this STAMP over time. C16G2 was monitored by LC/MS at a concentration of $100 \mu \mathrm{M}$ over $\sim 4.5 \mathrm{~h}$ at $37^{\circ} \mathrm{C}$ and the resulting C16G2 peak areas (TIC spectra) collected and fit to a single-order decay equation after subtraction of the saliva blank spectra. As shown in figure $5 \mathrm{~b}$, the data correlated well with the expected decay model, and utilizing the equation shown, $18.8 \mathrm{~min}$ was estimated for the half-life of $\mathrm{C} 16 \mathrm{G} 2$ in pooled human saliva.

The data in figure 5 indicate that C16G2 could be formulated in $1 \times$ PBS with at least overnight stability at $4^{\circ} \mathrm{C}$, and could be freshly prepared up to $4 \mathrm{~h}$ before treatment if stored at room temperature. The data also suggest that the peptide is stable in saliva for the duration of typical mouth rinse usage, after which it degrades, consistent with linear L-form peptides [Dickinson, 2002]. Overall, these results indicate that C16G2 has stability characteristics appropriate for formulation into a $1 \times$ PBS mouth rinse to evaluate selective killing of $S$. mutans in vivo.

\section{Clinical Overview}

From the results presented in figures $3-5$, it was clear that $\mathrm{C} 16 \mathrm{G} 2$ could remain stable in a $1 \times$ PBS formulation for sufficient time for robust activity against $S$. mutans biofilms. A clinical study was designed to explore the activity of single-application C16G2 rinse to selectively inhibit $S$. mutans growth in saliva and dental plaque over a 

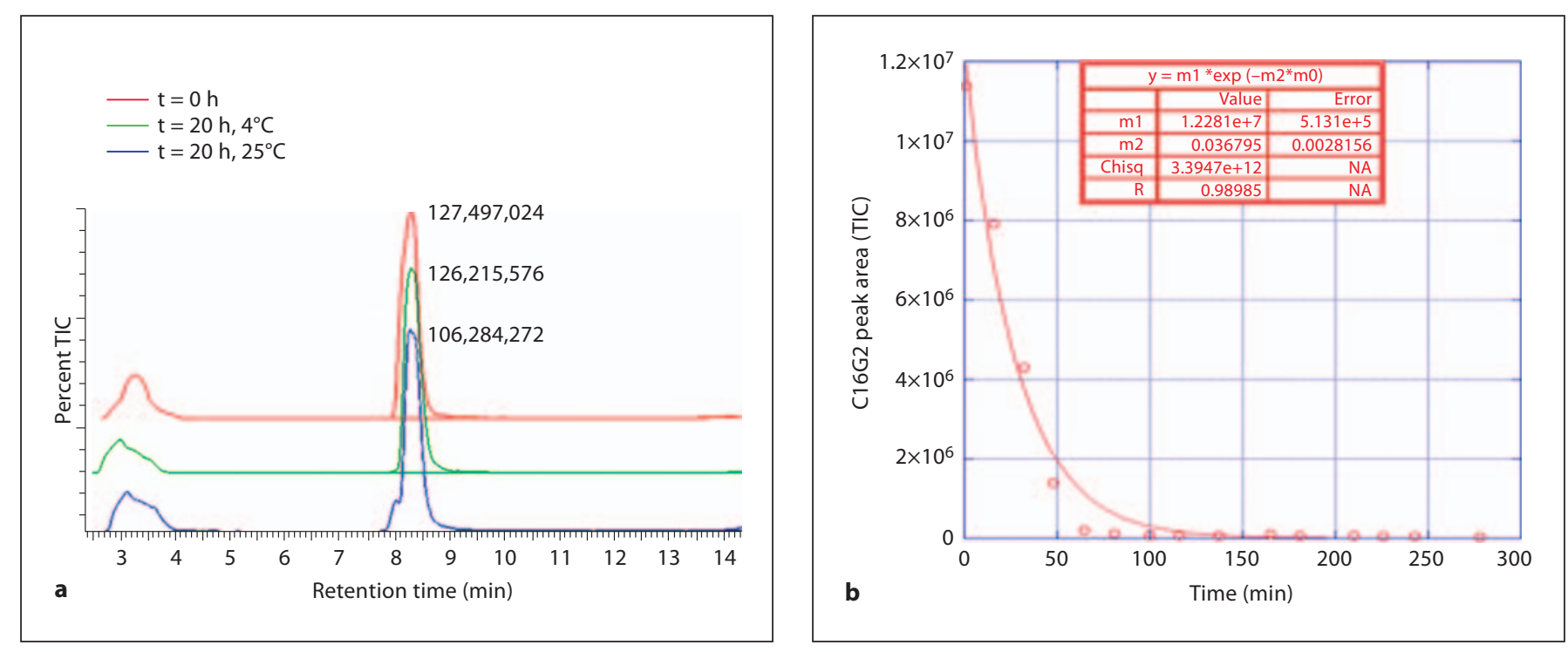

Fig. 5. Stability in $1 \times$ PBS and saliva. C16G2 $(100 \mu \mathrm{M})$ was mixed with $1 \times \mathrm{PBS}$ and held at 4 or $25^{\circ} \mathrm{C}$ for $20 \mathrm{~h}$ to assess stability (a). TIC spectra were overlayed and the C16G2 peak at $\sim 8.4$ min shown with peak area. The $\mathrm{y}$-axis for each spectrum was percent TIC (0 to 100). C16G2 (100 $\mu \mathrm{M})$ was mixed with prepared saliva (b) and monitored for the durations indicated. Remaining C16G2 peak areas (TIC spectra) were plotted to determine STAMP half-life.

4-day period, to measure its effects on plaque $\mathrm{pH}$ (resting and sucrose challenged), to measure its effect on lactic acid production after a sucrose challenge, and to determine if use of the C16G2 peptide could help prevent bacteria-induced mineral loss over a 4 -day test period. Panelists participating in this study were monitored for adverse clinical safety events and none were recorded.

\section{Effect of C16G2 on in vivo Plaque and Salivary}

S. mutans Levels

Selective plating and antibody staining were used to quantify the relative amounts of $S$. mutans collected from in vivo plaque and saliva samples, respectively, over a 4-day period after the initial use of the C16G2 and placebo rinses (fig. 6). The $\mathrm{cfu} / \mathrm{ml}$ of $S$. mutans in plaque samples (normalized by weight) was monitored for the placebo and active clinical phases at baseline before treatment and daily after treatment throughout the course of the study. As shown in figure 6a, the panelist group using the placebo rinse experienced a daily increase in $S$. $m u$ tans levels relative to baseline during the 4-day clinical period in which they were exposed to multiple daily sucrose challenges. In contrast, the $S$. mutans levels for the panelist group using the $0.04 \%$ C16G2 rinse experienced essentially no increase in $S$. mutans over the 4-day period despite the daily sucrose challenges. After 4 days, the levels of $S$. mutans decreased by $0.9 \log _{10} \mathrm{cfu} / \mathrm{ml}$ compared to baseline for those treated with the C16G2 rinse, whereas a $6.7 \log _{10} \mathrm{cfu} / \mathrm{ml}$ increase was experience for the group with the placebo. Repeated measures statistical analysis showed that the C16G2 rinse was significantly better than the placebo rinse in suppressing the levels of $S$. mutans throughout the course of the test period, and paired Student's t test showed that the C16G2 group had significantly lower levels of $S$. mutans than the placebo group at the conclusion of the study on day 4. A similar behavior was observed for salivary levels of $S$. mutans: $\mathrm{cfu} / \mathrm{ml}$ of $S$. mutans were increased on day 4 for the group using the placebo, while S. mutans from C16G2-treated panelists failed to increase over the study period and displayed a decreasing $\mathrm{cfu} / \mathrm{ml}$ trend (fig. $6 \mathrm{~b}$ ). The results in figure 6 suggest that $0.04 \%$ C16G2 rinse was effective in decreasing levels of plaque and salivary $S$. mutans and was very effective in preventing regrowth in spite of the frequent exposure to sugar during the test period. This is in contrast to the placebo which showed significant growth of $S$. mutans during the test period. The C16G2 rinse was significantly more effective at suppressing $S$. mutans growth on day 4 than the placebo rinse ( $p<0.001$, unpaired Student's t test). 

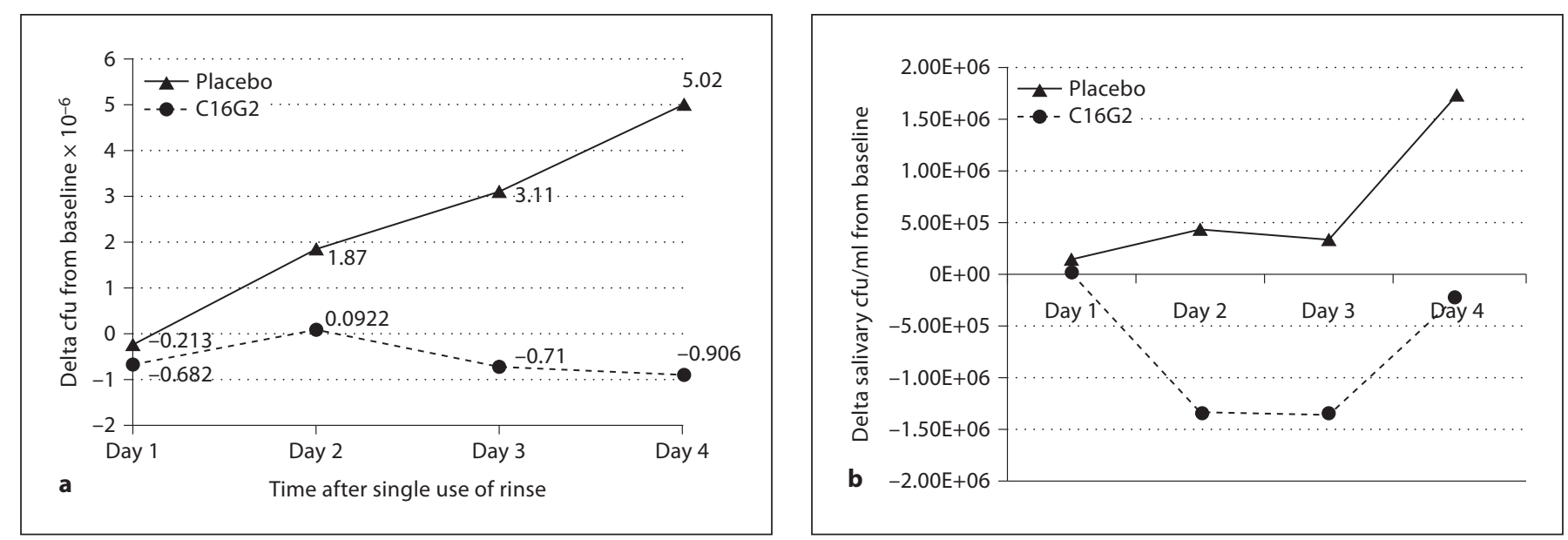

Fig. 6. S. mutans in plaque and saliva after STAMP and placebo treatment. Plaque (a) and salivary (b) cfu/ml were monitored daily from panelists treated with placebo $(\boldsymbol{\Delta})$ or C16G2 (๑) rinse. Placebo treatment was associated with an increase in $S$. mutans $\mathrm{cfu} / \mathrm{ml}$ over baseline, while STAMP treatment resulted in a reduction in S. mutans from baseline.

Impact of C16G2 on Relative Levels of S. mutans,

S. gordonii, S. sanguinis, and Total Bacteria Levels in

Dental Plaque by Real-Time PCR

Real-time PCR was used to quantify the relative amounts of S. mutans, S. gordonii, S. sanguinis, and total bacteria levels in dental plaque after 2 and 4 days following single use of the placebo and C16G2 rinses to demonstrate selectivity of C162G2 for S. mutans. The S. mutans, S. gordonii, and S. sanguinis levels were normalized by expressing them as a percent of the total bacteria levels. The realtime PCR results are shown in table 2. For the C16G2 rinse, the percent $S$. mutans levels exhibited no significant increase in concentration from day 2 to day 4 after treatment. In contrast, the percent $S$. mutans levels for the placebo group significantly increased by a factor of 2 . At day 4 , the concentration of $S$. mutans in the plaque was significantly lower for the group treated with C16G2 rinse. The total bacteria, percent $S$. sanguinis, and percent $S$. gordonii all increased in a similar manner for both $\mathrm{C} 16 \mathrm{G} 2$ and placebo. Interestingly, the total number of bacteria on day 4 after treatment was essentially the same for the placebo and C16G2 rinses. The results of the PCR analysis strongly support the selective killing of S. mutans by C16G2.

\section{Impact of C16G2 on Resting Plaque pH and Lactic Acid Production}

The resting plaque $\mathrm{pH}$ was measured before administration of the test rinses and each day thereafter. The results are shown in figure 7a. During the course of the
Table 2. Bacteria levels as measured by real-time PCR

\begin{tabular}{llllll}
\hline Rinse & $\begin{array}{l}\text { Days post- } \\
\text { treatment }\end{array}$ & $\begin{array}{l}\text { S. mutans } \\
\%\end{array}$ & $\begin{array}{l}\text { S. sanguinis } \\
\%\end{array}$ & $\begin{array}{l}\text { S.gordonii } \\
\%\end{array}$ & $\begin{array}{l}\text { Total } \\
\text { bacteria }\end{array}$ \\
\hline C16G2 & 2 & 0.0411 & 0.116 & 1.45 & 4.94 \\
& 4 & 0.0458 & 0.339 & 3.42 & 8.77 \\
Placebo & 2 & 0.0408 & 0.0572 & 1.60 & 6.20 \\
& 4 & 0.107 & 0.143 & 2.49 & 8.78 \\
\hline
\end{tabular}

4-day test period, the average resting $\mathrm{pH}$ values were 7.14 and 6.66 for the C16G2 and placebo rinses, respectively. A repeated-measures two-factor ANCOVA analysis showed that the resting $\mathrm{pH}$ of the $\mathrm{C} 16 \mathrm{G} 2$ group was significant higher than in the placebo group over the course of 4 days post treatment. In comparison to baseline, the average resting $\mathrm{pH}$ of the placebo group was very similar to the baseline value (6.66 vs. 6.68). In contrast, the resting $\mathrm{pH}$ of the $\mathrm{C} 16 \mathrm{G} 2$ group significantly increased from 6.83 at baseline to an average value of 7.15 post treatment $(\mathrm{p}<0.05)$. The results of the $\mathrm{pH}$ analysis demonstrate that the effect of C16G2 on resting $\mathrm{pH}$ persists over a 4-day period post treatment, and this is likely a major reason for enhanced protection against enamel demineralization (as shown below).

The lactic acid production by plaque bacteria after a sucrose challenge was measured at baseline and daily (days 1-4). As shown in figure $7 \mathrm{~b}$, the average lactic acid 

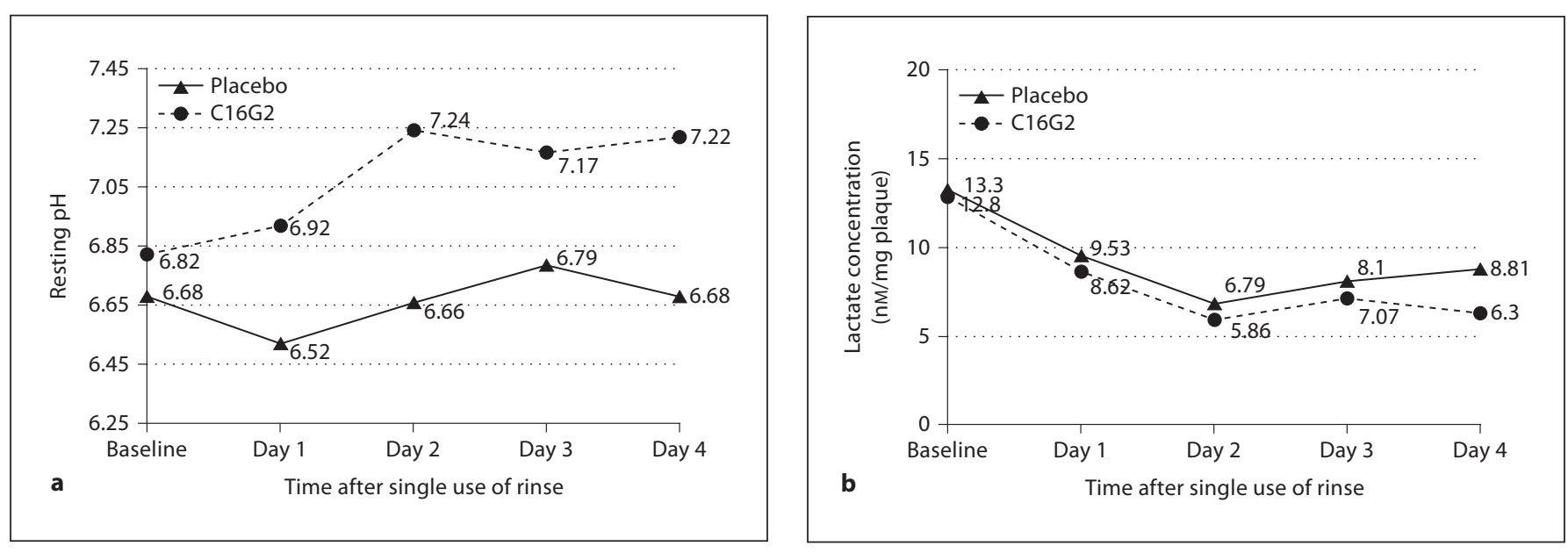

Fig. 7. Resting plaque $\mathrm{pH}$ and lactic acid production. The resting $\mathrm{pH}$ (a) of plaque samples was determined at baseline and daily after treatment. STAMP treatment was associated with higher $\mathrm{pH}$ when compared to placebo samples. Concurrently, the level of lactic acid production (b) was significantly lower in STAMP-treated samples than in placebo-treated samples after 4 days.

Table 3. Microhardness analysis

\begin{tabular}{lllll}
\hline Rinse & \multicolumn{2}{l}{ Knoop microhardness value } & $\begin{array}{l}\text { Decrease in } \\
\text { enamel hardness } \\
\text { post-treatment }\end{array}$ & $\begin{array}{l}\text { Demineral- } \\
\text { ization post- } \\
\text { treatment, \% }\end{array}$ \\
\hline C16G2 & 345.8 & 358.2 & -14.5 & -3.73 \\
Placebo & 337.2 & 257.6 & +82.5 & +23.0 \\
\hline
\end{tabular}

Values reported as least square means.

production over the 4 -day period post treatment was 8.64 and $6.93 \mu \mathrm{mol} / \mathrm{mg}$ plaque for the placebo and C16G2 rinses, respectively. In both rinse groups, lactic acid production decreased relative to baseline. A repeated-measures two-factor ANCOVA showed that the lactic acid production during the course of the 4-day treatment period was significantly lower for the C16G2 group ( $\mathrm{p}=$ $0.02)$

\section{C16G2-Associated Prevention of Mineral Loss}

In order to assess whether or not the selective killing of $S$. mutans in the plaque biofilm by C16G2 translates into significantly less enamel demineralization, the efficacy of the two rinses in preventing sugar-induced enamel demineralization was assessed using an intra-oral caries model. Enamel specimens were mounted in an upper palatal retainer and exposed to $10 \%$ sucrose challenges 4 times daily (days 1-4). Mineral changes before and after treatment were assessed using a microhardness tester. The results of the intra-oral caries study are shown in table 3 . The enamel specimens in the placebo rinse group experienced a $23.0 \%$ loss in enamel hardness after daily exposure of sucrose over the 4-day test period. The hardness of enamel specimens in the C16G2 group was not significantly different from the baseline value after the treatment period. In fact, there was a $3.73 \%$ average increase in enamel hardness relative to baseline. A two-factor ANOVA showed that the C16G2 rinse was significantly more effective in preventing enamel mineral loss than the placebo rinse. The results of the intra-oral caries model demonstrate that a single treatment with C16G2 rinse was highly effective in preventing enamel demineralization over a 4 -day period under the conditions of accelerated demineralization induced by frequent exposure to sucrose.

\section{Discussion}

In this report, we evaluated the in vitro and clinical efficacy of C16G2, a STAMP with activity against $S$. $m u$ tans. C16G2 was found to have robust activity against mature in vitro $S$. mutans biofilms and had a sufficient stability and safety profile for clinical evaluation. In the clinical study reported in this paper, the activity of C16G2 on dental plaque was assessed in conjunction with the end benefit of preventing enamel demineraliza- 
tion using an intra-oral caries model that represents conditions of accelerated demineralization induced by frequent sucrose exposure. The conditions used in this clinical trial are highly favorable for acid production and the proliferation of cariogenic organisms, and it represents an excellent model to test the hypothesis that selective killing of $S$. mutans can be an effective therapy for preventing enamel demineralization. The oral hygiene regimen used in this study was minimal. A 40 s rinse with a mouth rinse formulation containing 0.04\% C16G2 was administered only once at the start of the 4-day test phase and no fluoride toothpaste was used during this time period.

It was observed that C16G2 was highly effective in stopping the growth of $S$. mutans during the course of this study. The fact that the placebo group showed a significant increase in the relative amounts of $S$. mutans confirms that conditions were very favorable for growth of this organism and supports the potency of C16G2 killing. The real-time PCR data suggest that the killing is selective: there was no significant difference between the total bacteria levels for the C16G2 and placebo groups and the total amount of bacteria as well as the relative amounts of the oral streptococci S. gordonii and S. sanguinis, which all increased during the course of the study for both treatments.

It has been debated in the literature whether the initiation and progression of caries is caused primarily by a single pathogen such as $S$. mutans or a group of cariogenic bacteria [Loesche, 1986; Beighton, 2005; Tsang et al., 2006]. The results of this study indicate that selective elimination of $S$. mutans has a profound effect on the pathogenicity of the dental plaque. An interesting and unexpected observation of this study was the plaque $\mathrm{pH}$ effect; C16G2 was shown to significantly elevate the resting $\mathrm{pH}$ of dental plaque relative to the placebo rinse. This is beneficial from two perspectives: First, a higher resting $\mathrm{pH}$ increases the degree of saturation with respect to enamel, which promotes faster remineralization and decreases the severity of subsequent acid challenges created during the consumption of sugars. Second, the higher resting $\mathrm{pH}$ creates conditions that are favorable for growth of healthy bacteria and unfavorable for cariogenic (acidoduric) bacteria. This may be in part responsible for helping keep the $S$. mutans population from recovering in spite of the frequent exposure to sugar. The effects of $\mathrm{C} 16 \mathrm{G} 2$ on dental plaque translated into a significant benefit in protecting enamel against demineralization, as the enamel specimens in the C16G2 group did not experience any significant loss in mineral whereas the pla- cebo group experienced significant loss in mineral over the test periods. Other acid-producing organisms, such as S. sobrinus or Lactobacillus casei, which are known to be largely unaffected by C16G2 in vitro [Eckert et al., 2006a], were not able to take advantage of the high sucrose exposure and to contribute significantly to enamel demineralization. In summary, the results of this study strongly support the hypothesis that $S$. mutans is the critical and central facilitator of caries development, at least for caries linked to intake of dietary sugars and not resulting from pre-existing pathologies. Furthermore, these data suggest that it may be possible to generate a 'healthy' non-cariogenic microbial ecology in the oral cavity through STAMP intervention at the clinical level, as has been demonstrated in vitro. An intact dental plaque without $S$. mutans could resist future exogenous S. mutans colonization, or overgrowth due to sucrose consumption, and could delay or postpone cariogenesis. A more definitive clinical assessment with longer time periods and broader and larger populations will need to be completed to confirm this hypothesis and to determine whether unexpected cariogenic organisms fill in the $S$. mutans niche over time.

A key to any effective therapy for caries is the applicability of the technology to reach a broad population and its ability to fit into a normal oral hygiene regimen. A rinse is a vehicle that meets these criteria, and the stability and efficacy data presented indicate that such a formulation is achievable for this peptide. C16G2 was stable in $1 \times$ PBS for at least 1 day, without excipients or stabilizers, and remained active and capable of penetrating dental plaque to inhibit $S$. mutans. Used at infrequent intervals, a STAMP-containing rinse could complement professional and consumer oral care products that treat demineralization through use of fluoride. Conventional tooth brushing and other mouth rinses with non-specific activity would also work in concert with a C16G2 treatment, provided the latter was initially utilized to obtain a new microbial 'healthy plaque' status quo that can be maintained by standard oral hygiene. With the full range of excipients available during formal formulation development, we are confident that a 'shelf-stable' rinse can be constructed for C16G2.

The half-life of C16G2 in saliva was calculated as $18.8 \mathrm{~min}$, suggesting the peptide is unlikely to be retained at meaningful quantities in the oral cavity after long durations, which bodes well for a favorable safety profile. Given the relatively rapid antimicrobial activity of C16G2 against $S$. mutans in vitro, it is not surprising to observe the anti-S. mutans activity reported here, despite the in- 
herent susceptibility of the STAMP to proteolysis. This is in contrast to chlorhexidine and other antiseptic products used in dentistry, where retention to the tooth surface, soft tissue, or plaque is considered key for efficacy given the antimicrobial speed and relatively poor potency of these compounds. Full analyses are underway to investigate STAMP long-term stability and systemic absorption after a 40 s rinse treatment.

From the in vitro and placebo-controlled clinical data presented, it is clear that C16G2 has antimicrobial efficacy that is selective for $S$. mutans when formulated in a rudimentary mouth rinse. A single STAMP treatment was able to selectively eliminate $S$. mutans from plaque and salivary bacterial populations while leaving the remaining flora relatively undisturbed. This resulted in a S. mutans-free 'healthy plaque' that resisted $S$. mutans overgrowth despite sucrose challenges of up to 4 times daily for the entire course of treatment. A reduction of
S. mutans resulted in a higher resting plaque $\mathrm{pH}$, lower lactic acid production, and a significant reduction in enamel demineralization. The STAMP C16G2 may represent a remarkably effective weapon against dental caries that is easy to formulate, easy to administer, complements existing oral hygiene regimens, and can be dosed infrequently compared to other oral care ingredients.

\section{Acknowledgements}

We thank Erin Cavanaugh and Benjamin Webber for data collection and technical assistance. This study was supported by funds from C3 Jian Inc., CP and NIH grants (MD01831 and DE20102). The public funders had no role in the study design, the data collection and analysis, or the preparation of the manuscript and the decision to publish it. R.S., P.S., S.L., Z.L., M.H.A., W.S., and R.E. contributed to the manuscript and experimental design. E.G. and J.H. made contributions to experimental design and data collection.

\section{References}

Anderson MH, Shi W: A probiotic approach to caries management. Pediatr Dent 2006;28: 151-153; discussion 192-198.

Anonymous: National health expenditure projections 2008-2018; in Services USCfMaM (ed). Office of the Actuary, 2008.

Beighton D: The complex oral microflora of high-risk individuals and groups and its role in the caries process. Community Dent Oral Epidemiol 2005;33:248-255.

- Blondelle SE, Simpkins LR, Perez-Paya E, Houghten RA: Influence of tryptophan residues on melittin's hemolytic activity. Biochim Biophys Acta 1993;1202:331-336.

- Carounanidy U, Sathyanarayanan R: Dental caries: A complete changeover, part iii: Changeover in the treatment decisions and treatments. J Conserv Dent 2010;13:209-217.

-Corby PM, Lyons-Weiler J, Bretz WA, Hart TC, Aas JA, Boumenna T, Goss J, Corby AL, Junior HM, Weyant RJ, Paster BJ: Microbial risk indicators of early childhood caries. J Clin Microbiol 2005;43:5753-5759.

Damen JJ, Buijs MJ, ten Cate JM: Acidogenicity of buccal plaque after a single rinse with amine fluoride-stannous fluoride mouthrinse solution. Caries Res 2002;36:53-57.

Dickinson DP: Cysteine peptidases of mammals: Their biological roles and potential effects in the oral cavity and other tissues in health and disease. Crit Rev Oral Biol Med 2002;13:238275.

Eckert R, He J, Yarbrough DK, Qi F, Anderson $\mathrm{MH}$, Shi W: Targeted killing of Streptococcus mutans by a pheromone-guided 'smart' antimicrobial peptide. Antimicrob Agents Chemother 2006a;50:3651-3657.
Eckert R, Qi F, Yarbrough DK, He J, Anderson $\mathrm{MH}$, Shi W: Adding selectivity to antimicrobial peptides: Rational design of a multidomain peptide against Pseudomonas spp. Antimicrob Agents Chemother 2006b;50: 1480-1488.

Evans CA, Kleinman DV: The surgeon general's report on America's oral health: Opportunities for the dental profession. J Am Dent Assoc 2000;131:1721-1728.

Fennell JF, Shipman WH, Cole LJ: Antibacterial action of a bee venom fraction (melittin) against a penicillin-resistant staphylococcus and other microorganisms. USNRDL-TR67-101. Res Dev Tech Rep 1967:1-13.

- Gerardu VA, Buijs M, van Loveren C, Ten Cate JM: Plaque formation and lactic acid production after the use of amine fluoride/stannous fluoride mouthrinse. Eur J Oral Sci 2007;115: 148-152.

Gobor T, Corol G, Ferreira LE, Rymovicz AU, Rosa RT, Campelo PM, Rosa EA: Proposal of protocols using D-glutamine to optimize the 2,3-bis(2-methoxy-4-nitro-5-sulfophenly)5-[(phenylamino) carbonyl]-2h-tetrazolium hydroxide (XTT) assay for indirect estimation of microbial loads in biofilms of medical importance. J Microbiol Methods 2011;84: 299-306.

Gu F, Lux R, Anderson MH, del Aguila MA, Wolinsky L, Hume WR, Shi W: Analyses of Streptococcus mutans in saliva with speciesspecific monoclonal antibodies. Hybrid Hybridomics 2002;21:225-232.
He J, Yarbrough DK, Kreth J, Anderson MH, Shi W, Eckert R: Systematic approach to optimizing specifically targeted antimicrobial peptides against Streptococcus mutans. Antimicrob Agents Chemother 2010;54:2143-2151.

-He X, Lux R, Kuramitsu HK, Anderson MH, Shi W: Achieving probiotic effects via modulating oral microbial ecology. Adv Dent Res 2009;21:53-56.

Izco JM, Tormo M, Jimenez-Flores R: Rapid simultaneous determination of organic acids, free amino acids, and lactose in cheese by capillary electrophoresis. J Dairy Sci 2002; 85:2122-2129.

Kaplan CW, Sim JH, Shah KR, Kolesnikova A, Shi W, Eckert R: Selective membrane disruption: The mode of action of C16G2, a specifically targeted antimicrobial peptide. Antimicrob Agents Chemother 2011;55:34463452 .

Keene HJ, Shklair IL: Relationship of Streptococcus mutans carrier status to the development of carious lesions in initially cariesfree recruits. J Dent Res 1974;53:1295.

Keyes PH, White CL: Dental caries in the molar teeth of rats. III. Bio-assay of sodium fluoride and sodium lauroyl sarcosinate as caries-inhibitory agents. J Am Dent Assoc 1959; 58:43-55.

Koch G, Petersson LG, Ryden H: Effect of fluoride varnish (Duraphat) treatment every six months compared with weekly mouthrinses with 0.2 per cent $\mathrm{NaF}$ solution on dental caries. Swed Dent J 1979;3:39-44. 
- Li LN, Guo LH, Lux R, Eckert R, Yarbrough D, He J, Anderson M, Shi WY: Targeted antimicrobial therapy against Streptococcus mutans establishes protective non-cariogenic oral biofilms and reduces subsequent infection. Int J Oral Sci 2010;2:66-73.

Loesche WJ: Role of Streptococcus mutans in human dental decay. Microbiol Rev 1986;50: 353-380.

Marsh PD: Microbiology of dental plaque biofilms and their role in oral health and caries. Dent Clin North Am 2010;54:441454.

- Pitanga Fernandes ET, Duarte Vargas AM, Oliveira AC, Camargo da Rosa MA, Dutra Lucas S, Ferreira EFE: Factors related to dental caries in adolescents in southeastern Brazil. Eur J Paediatr Dent 2010;11:165170 .
Sawai MV, Waring AJ, Kearney WR, McCray PB Jr, Forsyth WR, Lehrer RI, Tack BF: Impact of single-residue mutations on the structure and function of ovispirin/novispirin antimicrobial peptides. Protein Eng 2002;15:225232.

Tanzer JM, Livingston J, Thompson AM: The microbiology of primary dental caries in humans. J Dent Educ 2001;65:1028-1037.

Tom D: Review: Increasing fluoride concentrations in toothpastes improved prevention of dental caries. Arch Dis Child Educ Pract Ed 2011;96:159.

Tong Z, Dong L, Zhou L, Tao R, Ni L: Nisin inhibits dental caries-associated microorganism in vitro. Peptides 2010;31:2003-2008.

Tsang PW, Qi F, Huwig AK, Anderson MH, Wesley D, Shi W: A medical approach to the diagnosis and treatment of dental caries. AHIP Cover 2006;47:38-42.

-Vaucher RA, Teixeira ML, Brandelli A: Investigation of the cytotoxicity of antimicrobial peptide p40 on eukaryotic cells. Curr Microbiol 2010;60:1-5.
Vollmer WM, Papas AS, Bader JD, Maupome G, Gullion CM, Hollis JF, Snyder JJ, Fellows JL, Laws RL, White BA: Design of the prevention of adult caries study (PACS): A randomized clinical trial assessing the effect of a chlorhexidine dental coating for the prevention of adult caries. BMC Oral Health 2010;10:23.

Williams MI, Cummins D: The technology behind Colgate Total Advanced Fresh. Compend Contin Educ Dent 2003;24:4-9, quiz 42.

Young DA, Lyon L, Azevedo S: The role of dental hygiene in caries management: A new paradigm. J Dent Hyg 2010;84:121-129.

Zhu WL, Nan YH, Hahm KS, Shin SY: Cell selectivity of an antimicrobial peptide melittin diastereomer with $\mathrm{D}$-amino acid in the leucine zipper sequence. J Biochem Mol Biol 2007;40:1090-1094. 